Водные биоресурсы и среда обитания 2018, том 1, номер 3-4, с. 45-55

http://journal.azniirkh.ru, www.azniirkh.ru ISSN 2618-8147 print, ISSN 2619-1024 online

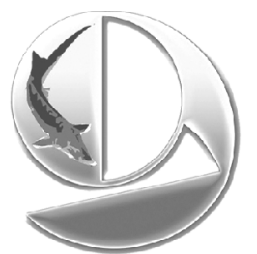

Aquatic Bioresources \& Environment

2018, vol. 1, no. 3-4, pp. 45-55

http://journal.azniirkh.ru, www.azniirkh.ru

ISSN 2618-8147 print, ISSN 2619-1024 online

Биология и экология гидробионтов

УДК 628.394:582.26(28)

\title{
RESPONSE OF ALGAL DIVERSITY TO PHYSICOCHEMICAL PARAMETERS OF POLLUTED WATERS IN SPRING LOW WATER SEASON IN DISTRICT CHARSADDA, PAKISTAN
}

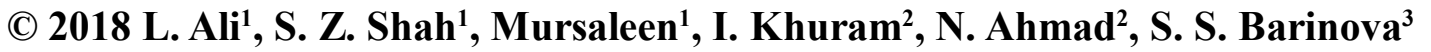 \\ ${ }^{1}$ University of Peshawar, Department of Botany, Islamia College University, Peshawar, \\ Khyber Pakhtunkhwa, Old Jamrud Road, Pakistan, PK-25120 \\ ${ }^{2}$ University of Peshawar, Department of Botany, Khyber Pakhtunkhwa, Old Jamrud Road, Pakistan, PK-25120 \\ ${ }^{3}$ Institute of Evolution, University of Haifa, Haifa 3498838, Israel \\ E-mail:mursaleen346@gmail.com; nadeemgul77@gmail.com; sophia@evo.haifa.ac.il
}

\begin{abstract}
The first investigation of the algal communities from the Jindi River revealed 93 algal species from five taxonomic divisions, identified in 90 samples collected at three sites of the river during the low water season in March-May of 2016. The total species richness increased from the upper sites of Shabqadar (45 species) and Tangi (51) to the lower site of Charsadda (59). Environmental conditions fluctuated insignificantly. The water in the studied water body was estimated as fresh, low saline, mid alkaline with $\mathrm{pH}$ increasing to the lower site of Charsadda up to 9.8. The programs CANOCO and Statistica 12.0 as well as Pearson correlation coefficients were applied, revealing two major parameters (ammonia and dissolved oxygen) as factors, influencing algal diversity. The river water was characterized as moderately polluted with increasing of transparency and algal diversity downstream that allows to conclude that the ecosystem of the Jindi R. has high self-purification ability with revealed algal community.
\end{abstract}

Keywords: aquatic communities, algae, water, physical parameters, chemical parameters, Pakistan

\section{РЕАКЦИЯ РАЗНООБРАЗИЯ ВОДОРОСЛЕЙ НА ФИЗИКО-ХИМИЧЕСКИЕ ПАРАМЕТРЫ ЗАГРЯЗНЕННЫХ ВОД В ВЕСЕННИЙ МАЛОВОДНЫЙ СЕЗОН В ОКРУГЕ ЧАРСАДДА, ПАКИСТАН}

\author{
Л. Али ${ }^{1}$, С. З. Шах ${ }^{1}$, Мурсалин $^{1}$, И. Хурам², Н. Ахмад ${ }^{2}$, С. С. Баринова ${ }^{3}$ \\ ${ }^{1}$ Факультет ботаники, Университет Исламия-Колледж, Пешавар, Хайбер-Пахтунхва, \\ Олд Джамруд Роуд, Пакистан, ПК-25120
}




\author{
${ }^{2}$ Факультет ботаники, Пешаварский университет, Хайбер-Пахтунхва, \\ Олд Джамруд Роуд, Пакистан, ПК-25120 \\ ${ }^{3}$ Институт эволюиии, Хайфский университет, Хайфа 3498838, Израиль \\ E-mail:mursaleen346@gmail.com; nadeemgul77@gmail.com; sophia@evo.haifa.ac.il
}

\begin{abstract}
Аннотация. Первое исследование водорослевых сообществ р. Джинди (Пакистан), заключавшееся в отборе 90 проб на трех участках реки во время маловодного сезона в марте-мае 2016 г., выявило 93 вида водорослей, принадлежащих к пяти таксономическим отделам. Общее видовое богатство повышалось от верхних участков Шабкадара (45 видов) и Танги (51 вид) к нижнему участку Чарсадда (59). Параметры окружающей среды варьировали незначительно. Установлено, что вода в реке пресная, с низким уровнем солености и средней щелочностью с рН, повышающимся к нижнему участку Чарсадда до уровня 9,8. Использование программ CANOCO и Statistica 12.0, а также коэффициентов корреляции Пирсона показало зависимость видового разнообразия водорослей от двух важных параметров - аммиака и растворенного кислорода. Вода в реке была охарактеризована как умеренно загрязненная; увеличение прозрачности и видового разнообразия водорослей вниз по течению реки позволило предположить, что экосистема р. Джинди имеет высокую способность к самоочищению с помощью выявленного водорослевого сообщества.
\end{abstract}

Ключевые слова: водоросли, химический состав воды, физико-химические параметры, Пакистан

\section{INTRODUCTION}

Water pollution is a serious problem in Pakistan, which causes a serious threat to aquatic life as well as to human beings. An effluent from industries, hospitals, municipal wastes and house drains into water bodies is increasing a number of pollutants in these water bodies, making water unfavorable for all kinds of aquatic life. These untreated wastewaters are basically discharged into the water bodies and agricultural lands, which causes even more pollution during spring low water season. Thus, these waste waters must be treated before using them for agricultural purposes [1]. Biological monitoring is the use of biological response to assess changes in the environment, generally changes due to anthropogenic causes. Certain aquatic plants including algae have also been used as indicator species for pollutants including nutrient enrichment [2]. Even the presence or absence of the indicator or of an indicator species or an indicator community reflects environmental conditions. So, species richness in algal communities can indicate the environmental changes. The diatoms, blue-green algae and colored flagellates (particularly Chrysophyta and Euglenophyta) are best known algae for water pollution problems with water supplies, but green algae may also be involved.

Algae occupy different substrates in polluted and unpolluted waters; due to this behavior they are generally considered useful to determine the water quality. The value of algae as bio-monitors and bioindicators had already been recognized in the mid XIX century: the first concept which had been developed was the system of saprobity. It was mainly designed for organic pollution of streams and rivers [3, 4]. Algae are found in almost all aquatic habitats. They are also among the short generation times of all biological indicators, allowing them to respond rapidly to environmental changes and to provide an early warning of potential changes in nutrient status for different water bodies [5]. Algal communities research in Pakistan demonstrated very productive results for the water quality and environment changes monitoring [6-12], which includes two steps: (1) species richness revealing and (2) bio-indication based on species ecology.

The aim of the present study was to reveal the species richness of algae,which had never been studied before in the area of the Jindi River (three sites of Charsadda Region) during the spring low water season.

\section{MATERIALS AND METHODS}

Sampling. To study the impact of the polluted water on the algae diversity in the Jindi River, which flows across all three tehsils of district Charsadda, three research sites were chosen: tehsil Charsadda, tehsil Tangi and tehsil Shabqadar (fig. 1). A total of 90 samples of periphyton algae (about 30 samples per site during three monthly field trips) were collected from each research site by means of scratching them from the substrates. Altogether, 90 water samples were collected simultaneously with the algal ones from the Jindi River in spring 2016 (from March 15 to May 15). Sampling was conducted from ten different spots on the site randomly. The specimens were washed carefully, placed 


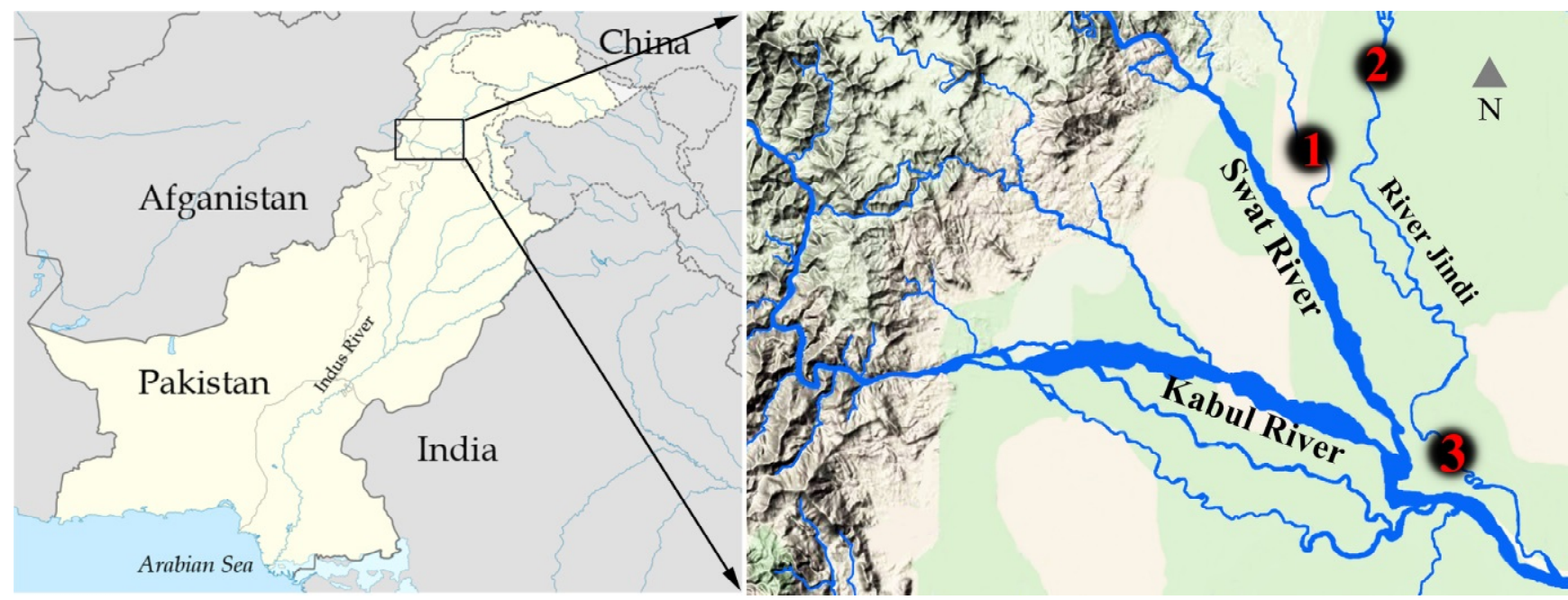

Fig. 1. Sampling sites in the Jindi River from 15 March to 15 May, 2016: 1 - Tehsil Shabqadar; 2 - Tehsil Tangi; 3 - Tehsil Charsadda

Рис. 1. Участки отбора проб на реке Джинди 15 марта - 15 мая 2016 г.: 1 - техсил Шабкадар; 2 - техсил Танги; 3 - техсил Чарсадда

into the sampling tubes, and preserved in the $4 \%$ neutral formaldehyde solution, partly using the Utermöhl method, and kept for a long time to avoid spoilage [13].

Description of the study site. The Jindi River begins in the hills of Malakand Agency, in the northern district of Charsadda, Khyber-Pakhtunkhwa, Pakistan. The Jindi River is located in the north of Pakistan, being the left tributary of the Swat River, where in the lower reaches in the south of Charsadda it joins with the Kabul River, the right large tributary of the Indus River (fig. 1) [14]. During the early months of each year, the Jindi River has a very limited water supply, but the summer months bring with them much needed rain to water the area. As the river proceeds downstream, the local people use dams, similar to the Warsak Dam on the Kabul River, to take out water for irrigation; therefore, the amount of water flowing downstream decreases. The area surrounding the Kabul and Jindi rivers is one of the largest irrigated areas within KhyberPakhtunkhwa [14]. This coupled with an exponentially growing population alludes to problems in the future. The Jindi River used to have enough water to sustain the surrounding area, but over the last few years, due to the environmental changes including massive droughts and rising global temperatures, the river does not. This, along with growing water pollution, makes the ability to acquire fresh clean water detrimental to the area and its surrounding population. The Jindi River has one tributary, where the samples were taken from. The investigated river basin as a whole is located in the flat Peshawar Valley, where agriculture is much developed and settlements are very numerous. Many agricultural and domestic wastewaters are inputted into the mentioned river [15]. The related climatic parameters have two seasonalities $[6,15]$ and the lower water season falls between March and June. Thus, the most appropriate time during the low water season was chosen for revealing the influence of water quality on the algal communities.

Laboratory processing. Methods used for the chemical analysis were standardized according to the procedures given by APHA-AWWA-WPCF [16] and processed in the PCSIR laboratories, Peshawar. Microscopic morphology of the non-Diatomaceous algae was determined by using the wet-mount staining method [13]. This was done by using a sterile forceps to pick up algal filaments from temporarily preserved samples and placing onto a clean glass slide, on which a drop of distilled water was added. A drop of transparent oil was then added, and the preparation was covered with clean cover slips. The slides were subsequently viewed under $10 \times, 40 \times$ and $100 \times$ Nikon Eclipse E200 microscope objectives. Images of the taxa were taken with a BRESSER digital microscope.

In order to identify the algal species, the picture from an algal specimen was taken with the help of a digital camera. These pictures were identified with the help of standard monographs of available literature, research papers, publications keys and some microphotographs [17-19]. Some isolates were not identified up to a species level because of the absence of their reproductive structure and characteristic features. 
Modern taxonomic names and system were taken from algaebase.org.

Statistical calculation of the Pearson correlation coefficients was done in the wessa.net. Statistica 12.0 and CANOCO programs were used for calculation of relationships between species richness in taxonomic divisions and environmental variables on the sampling sites.

\section{RESULTS}

Altogether, 93 algal species from five taxonomic divisions were revealed from 90 samples collected in the Jindi River during the low water season in MarchMay of 2016 (table 1).

The species of Charophyta significantly prevailed including 28 taxa (table 2). The second in species

Table 1. Distribution of algal species in different tehsils of district Charsadda in spring season

Таблица 1. Распространение видов водорослей в разных техсилах района Чарсадда весной

\begin{tabular}{|c|c|c|c|}
\hline Таха / Таксоны & $\mathrm{S}$ & $\mathrm{T}$ & $\mathrm{C}$ \\
\hline 1 & 2 & 3 & 4 \\
\hline \multicolumn{4}{|l|}{ Bacillariophyta } \\
\hline Amphora ovalis (Kützing) Kützing & 1 & 0 & 0 \\
\hline Caloneis bacillum (Grunow) Cleve & 1 & 0 & 1 \\
\hline Cocconies sp. & 0 & 1 & 0 \\
\hline Craticula ambigua (Ehrenberg) D.G. Mann & 0 & 1 & 0 \\
\hline Cymbella hustedtii Krasske & 1 & 1 & 0 \\
\hline Cymbella sp. & 0 & 0 & 1 \\
\hline Cymbopleura cuspidata (Kützing) Krammer & 0 & 1 & 0 \\
\hline Fragilaria capucina Desmazières & 0 & 0 & 1 \\
\hline Fragilaria crotonensis Kitton & 0 & 0 & 1 \\
\hline Fragilaria sp. & 1 & 1 & 1 \\
\hline Frustulia rhomboides (Ehrenberg) De Toni & 1 & 0 & 1 \\
\hline Frustulia saxonica Rabenhorst & 1 & 1 & 0 \\
\hline Gomphonema angustatum (Kützing) Rabenhorst & 0 & 1 & 1 \\
\hline Gomphonema carolinense Hagelstein & 1 & 1 & 1 \\
\hline Gomphonema olivaceum (Hornemann) Brébisson & 0 & 0 & 1 \\
\hline Navicula amphiceropsis Lange-Bertalot \& U. Rumrich & 0 & 1 & 1 \\
\hline Navicula cryptocephala Kützing & 1 & 1 & 1 \\
\hline Navicula gregaria Donkin & 1 & 1 & 1 \\
\hline Navicula phyllepta Kützing & 1 & 0 & 0 \\
\hline Navicula radiosa Kützing & 1 & 1 & 0 \\
\hline Navicula sp. & 0 & 1 & 1 \\
\hline Neidium ampliatum (Ehrenberg) Krammer & 0 & 1 & 1 \\
\hline Nitzschia palea (Kützing) W. Smith & 0 & 1 & 0 \\
\hline Nitzschia vitrea G. Norman & 1 & 1 & 0 \\
\hline Pleurosigma angulatum (J.T. Quekett) W. Smith & 0 & 1 & 0 \\
\hline Tryblionella hungarica (Grunow) Frenguelli & 1 & 0 & 0 \\
\hline \multicolumn{4}{|l|}{$\begin{array}{ll}\text { Charophyta } \\
\end{array}$} \\
\hline Chara aspera C.L. Willdenow & 1 & 1 & 1 \\
\hline Chara canescens Loiseleur & 1 & 0 & 1 \\
\hline Chara globularis Thuiller & 0 & 1 & 1 \\
\hline Closterium lunula Ehrenberg \& Hemprich ex Ralfs & 1 & 0 & 1 \\
\hline Closterium ralfsii Brébisson ex Ralfs & 1 & 1 & 1 \\
\hline Cosmarium quadrifarium P. Lundell & 0 & 1 & 0 \\
\hline Sirogonium sticticum (Smith) Kützing & 0 & 1 & 1 \\
\hline Spirogyra aequinoctialis G.S. West & 1 & 0 & 1 \\
\hline Spirogyra communis (Hassall) Kützing & 1 & 0 & 0 \\
\hline Spirogyra condensata (Vaucher) Dumortier & 0 & 1 & 1 \\
\hline Spirogyra crassa (Kützing) Kützing & 0 & 1 & 0 \\
\hline
\end{tabular}


Table 1 (continued)

Таблица 1 (продолжение)

\begin{tabular}{|c|c|c|c|}
\hline 1 & 2 & 3 & 4 \\
\hline Spirogyra daedalea f. daedaloides (Czurda) V. Poljansky & 0 & 0 & 1 \\
\hline Spirogyra decimina (O.F. Müller) Dumortier & 0 & 0 & 1 \\
\hline Spirogyra ellipsospora Transeau & 0 & 0 & 1 \\
\hline Spirogyra flavescens (Hassall) Kützing & 1 & 0 & 1 \\
\hline Spirogyra fluviatilis Hilse & 0 & 1 & 0 \\
\hline Spirogyra formosa (Transeau) Czurda & 1 & 1 & 1 \\
\hline Spirogyra jugalis (Dillwyn) Kützing & 0 & 1 & 0 \\
\hline Spirogyra neglecta var. fuellerbornei (Schmidle) Petlovany & 1 & 1 & 0 \\
\hline Spirogyra nova-angliae Transeau & 1 & 1 & 0 \\
\hline Spirogyra porticalis (O.F. Müller) Dumortier & 1 & 1 & 0 \\
\hline Spirogyra submaxima Transeau & 0 & 0 & 1 \\
\hline Spirogyra subsalsa Kützing & 0 & 1 & 0 \\
\hline Spirogyra varians (Hassall) Kützing & 1 & 0 & 1 \\
\hline Spirogyra sp. & 0 & 1 & 1 \\
\hline Temnogyra punctiformis (Transeau) Yamagishi & 1 & 1 & 0 \\
\hline Zygnema transeauianum G.C. Couch & 0 & 0 & 1 \\
\hline Zygnema sp. & 1 & 0 & 0 \\
\hline Chlorophyta & & & \\
\hline Chaetophora elegans (Roth) C. Agardh & 0 & 1 & 0 \\
\hline Chlamydomonas globosa J.W. Snow & 0 & 1 & 0 \\
\hline Chlamydomonas hydra $\mathrm{H} . \mathrm{Ettl}$ & 1 & 0 & 1 \\
\hline Chlamydomonas polypyrenoideum Prescott & 0 & 0 & 1 \\
\hline Chlamydomonas $\mathrm{sp}$. & 1 & 0 & 1 \\
\hline Chlorococcum aegyptiacum P.A. Archibald & 0 & 1 & 1 \\
\hline Chlorogonium elongatum (P.A. Dangeard) Francé & 1 & 0 & 0 \\
\hline Cladophora glomerata (Linnaeus) Kützing & 0 & 0 & 1 \\
\hline Cladophora rivularis (Linnaeus) Kuntze & 1 & 0 & 1 \\
\hline Dactylococcus infusionum Nägeli & 1 & 1 & 1 \\
\hline Edaphochlamys debaryana (Goroschankin) Pröschold \& Darienko & 0 & 0 & 1 \\
\hline Haematococcus lacustris(Girod-Chantrans) Rostafinski & 1 & 0 & 0 \\
\hline Hydrodictyonreticulatum (Linnaeus) Bory & 1 & 0 & 0 \\
\hline Microspora sp. & 0 & 0 & 1 \\
\hline Oedogonium sp. & 1 & 1 & 1 \\
\hline Palmella miniata Leiblein & 0 & 1 & 0 \\
\hline Pandorina morum (O.F. Müller) Bory & 0 & 0 & 1 \\
\hline Pandorina sp. & 0 & 1 & 1 \\
\hline Rhizoclonium sp. & 0 & 1 & 1 \\
\hline Sphaerocystis schroeteri Chodat & 1 & 0 & 0 \\
\hline Stigeoclonium farctum Berthold & 1 & 1 & 1 \\
\hline Ulothrix cylindrical Prescott & 0 & 1 & 1 \\
\hline Ulothrix tenerrima (Kützing) Kützing & 1 & 0 & 1 \\
\hline Ulothrix zonata (F. Weber \& Mohr) Kützing & 0 & 1 & 1 \\
\hline \multicolumn{4}{|l|}{ Cyanobacteria } \\
\hline Aphanocapsa grevillei (Berkeley) Rabenhorst & 1 & 1 & 0 \\
\hline Lyngbya aestuarii Liebman ex Gomont & 1 & 1 & 0 \\
\hline Lyngbya lutea Gomont ex Gomont & 0 & 0 & 1 \\
\hline Oscillatoria curviceps C. Agardh ex Gomont & 1 & 0 & 1 \\
\hline Oscillatoria major Vaucher ex Forti & 1 & 0 & 1 \\
\hline Oscillatoria princeps Vaucher ex Gomont & 0 & 0 & 1 \\
\hline Oscillatoria subbrevis Schmidle & 0 & 1 & 0 \\
\hline
\end{tabular}


Table 1 (finished)

Таблица 1 (окончание)

\begin{tabular}{|c|c|c|c|}
\hline 1 & 2 & 3 & 4 \\
\hline Oscilatoria sp. & 0 & 1 & 1 \\
\hline Phormidium lucidum Kützing ex Gomont & 0 & 0 & 1 \\
\hline Phormidium subfuscum Kützing ex Gomont & 0 & 1 & 1 \\
\hline \multicolumn{4}{|l|}{ Euglenophyta } \\
\hline Euglena elastic Prescott & 1 & 0 & 1 \\
\hline Euglena oblonga F. Schmitz & 0 & 0 & 1 \\
\hline Euglena sociabilis P.-A. Dangeard & 1 & 0 & 0 \\
\hline Euglena sp. & 1 & 1 & 1 \\
\hline Lepocinclis spirogyroides B. Marin \& Melkonian & 0 & 1 & 1 \\
\hline $\begin{array}{l}\text { Total species } \\
\text { Всего видов }\end{array}$ & 45 & 51 & 59 \\
\hline
\end{tabular}

Note: S - Shabqadar; T - Tangi; C - Charsadda. Presence: (1), Absence: (0).

Примечание: S - Шабкадар; T - Танги; C - Чарсадда. Наличие: (1), Отсутствие: (0).

Table 2. Distribution of algal species of taxonomic divisions in the sampling sites of the Jindi River in district Charsadda

Таблица 2. Распространение видов водорослей различных таксономических отделов на станциях отбора проб на реке Джинди в районе Чарсадда

\begin{tabular}{|c|c|c|c|c|}
\hline $\begin{array}{c}\text { Таха } \\
\text { Таксоны }\end{array}$ & $\begin{array}{l}\text { Shabqadar } \\
\text { Шабкадар }\end{array}$ & $\begin{array}{l}\text { Tangi } \\
\text { Танги }\end{array}$ & $\begin{array}{l}\text { Charsadda } \\
\text { Чарсадда }\end{array}$ & $\begin{array}{c}\text { Total in } \\
\text { division } \\
\text { Всего в } \\
\text { отделе }\end{array}$ \\
\hline Bacillariophyta & 13 & 17 & 14 & 26 \\
\hline Charophyta & 14 & 16 & 17 & 28 \\
\hline Chlorophyta & 11 & 11 & 17 & 24 \\
\hline Cyanobacteria & 4 & 5 & 7 & 10 \\
\hline Euglenophyta & 3 & 2 & 4 & 5 \\
\hline $\begin{array}{l}\text { Total on site } \\
\text { Всего на } \\
\text { участке }\end{array}$ & 45 & 51 & 59 & 93 \\
\hline
\end{tabular}

richness were those of Bacillariophyta (26), followed by Chlorophyta (24), and Cyanobacteria (10). Only 5 species of Euglenophyta were identified in the investigated areas. The species richness increased from the upper sites of Shabqadar and Tangi to the lower site of Charsadda (table 1). The algal community changed from Navicula-Spirogyra and NitzschiaSpirogyra on the upper sites to Cladophora-UlothrixSpirogyra-Oscillatoria in Charsadda.

High uniformity of the revealed diversity on all three sites should be taken into consideration. Whereas the total species richness of each division is difficult to compare, the ratios can give better trends of the diversity changes. Thus, fig. 2 shows the dynamics of species richness over three sites where the total species richness sufficiently increases down the river in Charsadda. It is necessary to mark that the major role on each site is played by diatoms, charophyte, and green algae. But the species richness was enriched by cyanobacteria on the lower site of Charsadda with a decrease of the diatom species ratio. It can be indicated as an impact of water pollution on the algal community where clear aquatic species of charophytes and diatoms are replaced by cyanobacteria with an increase of euglenoids at the same time.

Different physicochemical parameters studied during the research included temperature, $\mathrm{pH}$, turbidity, total dissolved solids, dissolved oxygen, total suspended solids, and ammonia following the standard method in PCSIR laboratories Peshawar (table 3). The water temperature in spring season varied insignificantly with a maximum $\left(26.5^{\circ} \mathrm{C}\right)$ in the upper site of Shabqadar (table 3).

High $\mathrm{pH}$ value ranging between 8.45 (the upper site of Tangi) to 8.96 (the upper site in tributary Shabqadar) reflects not only the climatic norm but also shows the pollution impact at the sites with the low water during the spring season (table 3 ).

The water turbidity value fluctuated at a range from 61 to 77 nephelometric turbidity units (NTU) and demonstrated a different influence of agricultural runoff at different sites (table 3).

Total dissolved solids (TDS) values also fluctuated insignificantly, which allows to estimate the river aquatic environment as freshwater with minimal salinity (table 3). Dissolved oxygen (DO) was sufficient for the aquatic life survival (table 3 ). Total suspended solids (TSS) parameter was higher in the upper site of Tangi with a value of $200 \mathrm{mg} / \mathrm{l}$, decreasing up to $136 \mathrm{mg} / \mathrm{l}$ in 

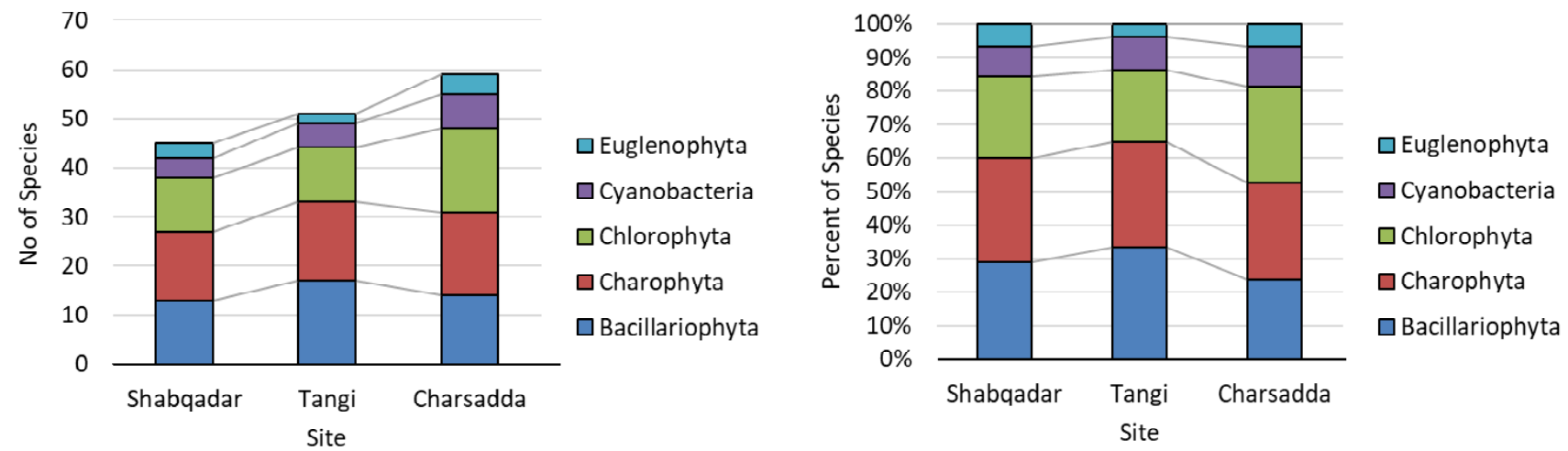

Fig. 2. Distribution of species richness (left) and ratio (right) in taxonomic divisions over sampling sites in the Jindi River basin in spring of 2016 (March 15 - May 15)

Рис. 2. Распределение видового богатства (слева) и соотношений (справа) в таксономических отделах на разных участках отбора проб в бассейне р. Джинди весной (с 15 марта по 15 мая 2016 г.)

the lower site of Charsadda (table 3), and reflected the increase of water transparency.

The ammonia concentration was maximal in Charsadda $(0.48 \mathrm{mg} / \mathrm{l})$, whereas at the upper sites it was significantly lower (table 3), which indicates that water is moderately polluted. That allows to assume that organic matter is enriching the river water from the upper sites to the lower ones.

Table 3. Averaged physicochemical parameters at sampling sites of the Jindi River, district Charsadda during March-May of 2016

Таблица 3. Усредненные физико-химические параметры на участках отбора проб на р. Джинди, округ Чарсадда, март-май 2016 г.

\begin{tabular}{|c|c|c|c|}
\hline $\begin{array}{l}\text { Parameter } \\
\text { Параметр } \\
\end{array}$ & $\begin{array}{l}\text { Shabqadar } \\
\text { Шабкадар }\end{array}$ & $\begin{array}{l}\text { Tangi } \\
\text { Танги }\end{array}$ & $\begin{array}{l}\text { Charsadda } \\
\text { Чарсадда }\end{array}$ \\
\hline $\begin{array}{l}\text { Temperature, }{ }^{\circ} \mathrm{C} \\
\text { Tемпература, }{ }^{\circ} \mathrm{C}\end{array}$ & 26.5 & 24.4 & 25.4 \\
\hline $\mathrm{pH}$ & 8.96 & 8.45 & 9.80 \\
\hline $\begin{array}{l}\text { Turbidity, NTU } \\
\text { Мутность }\end{array}$ & 88 & 61 & 77 \\
\hline $\begin{array}{l}\text { TDS, mg/l } \\
\text { Общее количество } \\
\text { растворенных } \\
\text { твердых веществ, } \\
\text { мг/л }\end{array}$ & 215 & 232 & 204 \\
\hline $\begin{array}{l}\mathrm{DO}, \mathrm{mg} / \mathrm{l} \\
\text { Растворенный } \\
\text { кислород, мг/л }\end{array}$ & 3.0 & 3.5 & 4.5 \\
\hline $\begin{array}{l}\text { TSS, mg/l } \\
\text { Общее количество } \\
\text { взвешенных твердых } \\
\text { частиц, мг/л }\end{array}$ & 172 & 200 & 136 \\
\hline $\begin{array}{l}\text { Ammonia, mg/l } \\
\text { Аммиак, мг/л }\end{array}$ & 0.38 & 0.44 & 0.48 \\
\hline
\end{tabular}

Changes of the environmental variables ratio can be estimated in fig. 3, where it is possible to observe the decrease of TSS and increase of water temperature and $\mathrm{pH}$ from the upper to lower sites.

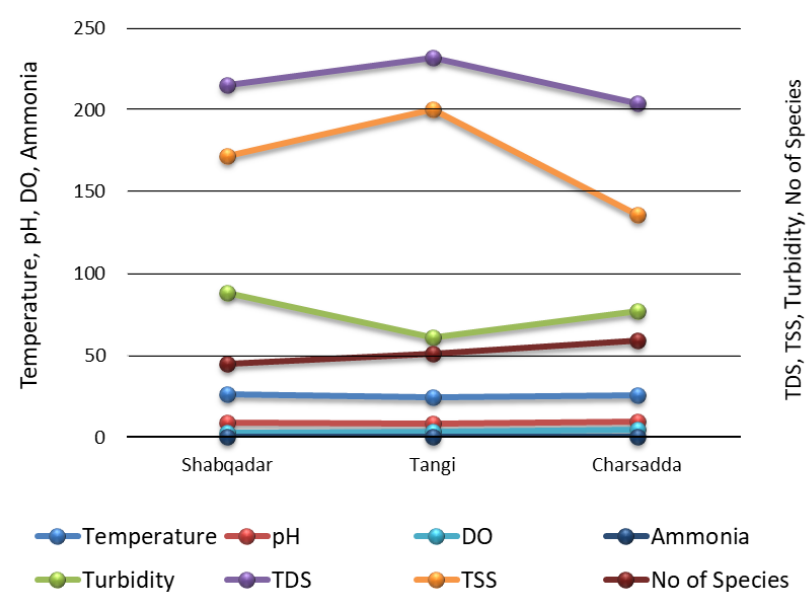

Fig. 3. Distribution of environmental variables at sampling sites in the Jindi R. in spring 2016

Рис. 3. Распределение параметров окружающей среды на участках отбора проб на р. Джинди весной 2016 г.

In order to reveal the major environmental factors that influenced algal diversity of the Jindi River, three different methods were applied. The species richness in the divisions (table 2) and environmental variables (table 3) were chosen as a basis of the relationships calculation. Firstly, the Pearson coefficients were calculated for each pair of the environmental and biological variables ${ }^{*}=$ Significant; $* *=$ Highly significant). It was found out that only two variables significantly correlated with species richness in the 
taxonomic divisions-dissolved oxygen $\left(0.994^{* *}\right)$ and ammonia $(0.980 * *)$. Simultaneously, both these environmental variables significantly correlated with each other $\left(0.953^{*}\right)$. We have found a negative correlation between species richness and water temperature $\left(-0.450^{*}\right)$, and positive correlation between species richness and water $\mathrm{pH}\left(0.678^{*}\right)$. All the other variables have no significant correlation between each other and species richness. Therefore, we can assume that algal communities can be influenced by the concentrations of ammonia and oxygen in the river water of the Jindi River basin.

Thus, it was decided to use other programs for a more detailed calculation of the species and environmental factors relationship. Canonical Correspondence Analysis (CCA) plot was constructed in the CANOCO program based on the data in tables 2 and 3. Fig. 4 shows the calculation results. There are three groups of environmental variables that influenced algal diversity of the studied sites. The first group represents four variables such as $\mathrm{pH}$, dissolved oxygen, ammonia, as well as species richness in the algal communities (multispecies community). All these variables positively influenced the community at only one lower site of Charsadda, at the same time this group of variables has a negative impact on the algae at the Shabqadar site. The second group of variables included two water parameters (TDS and TSS), which have positive influence on Tangi communities and affect negatively the Charsadda ones. The third group consisted of only one parameter (water temperature) that had significant influence on the community in Shabqadar but was indifferent for the other two. CCA plot on fig. 4 demonstrates very low sensitivity of the identified algal communities of the Jindi River to the water parameters during the low water season because on the plot the points of species richness in taxonomic divisions are placed close to the center of the triplot.

Thereafter, there was an attempt to reveal the major influential variables for species richness in the divisions because it is important to know which species contribute most to the process of self-purification of the river and which parameters hinder or stimulate this process. 3D Contour plots have been constructed for the mentioned above ammonia and dissolved oxygen concentrations. Fig. 5 shows that the total species richness was stimulated by both these parameters (ammonia and dissolved oxygen). The Charophytes endured certain ammonium concentrations but at the same time preferred low oxygen content in the water. Green algae

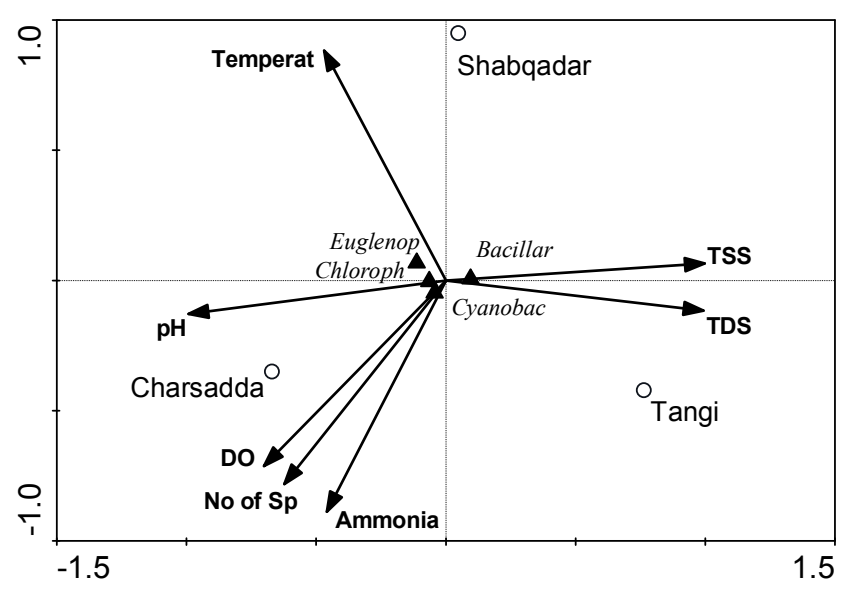

Fig. 4. Canonical Correspondence Analysis (CCA) plot of the division species richness and environmental variables at sampling sites in the Jindi River in spring 2016

Рис. 4. График канонического анализа соответствий (Canonical Correspondence Analysis - CCA) видового богатства в отделах и параметров окружающей среды на участках отбора проб на p. Джинди весной 2016 г.

were rather rich in the well oxygenated waters, but ammonia has a negative effect on their development. Simultaneously, cyanobacteria species increased in number with the oxygen concentration increase in the river water.

\section{DISCUSSION}

The Jindi River algal communities were studied for the first time and represented by 93 algal species from five taxonomic divisions revealed from 90 samples collected during the low water season in March-May of 2016. Charophyta significantly prevail among the identified 93 taxa and include 28 taxa (table 2). The similar distribution with prevailing of charophyte species was reported from the Kabul River [7-9]. Fluctuations of species richness over the sampling sites reveal that the total species richness increased down the river and was enriched by cyanobacteria on the lower site of Charsadda with the decrease of diatoms in the lower site community. It can be a result of the water pollution impact on the algal community which, on the one hand, stimulated total species richness and, on the other hand, changed the community composition. Thus, clear aquatic species of charophytes and diatoms were replaced by cyanobacteria with an increase of euglenoids at the same time.

Measured environmental variables such as water temperature during the spring season varied 

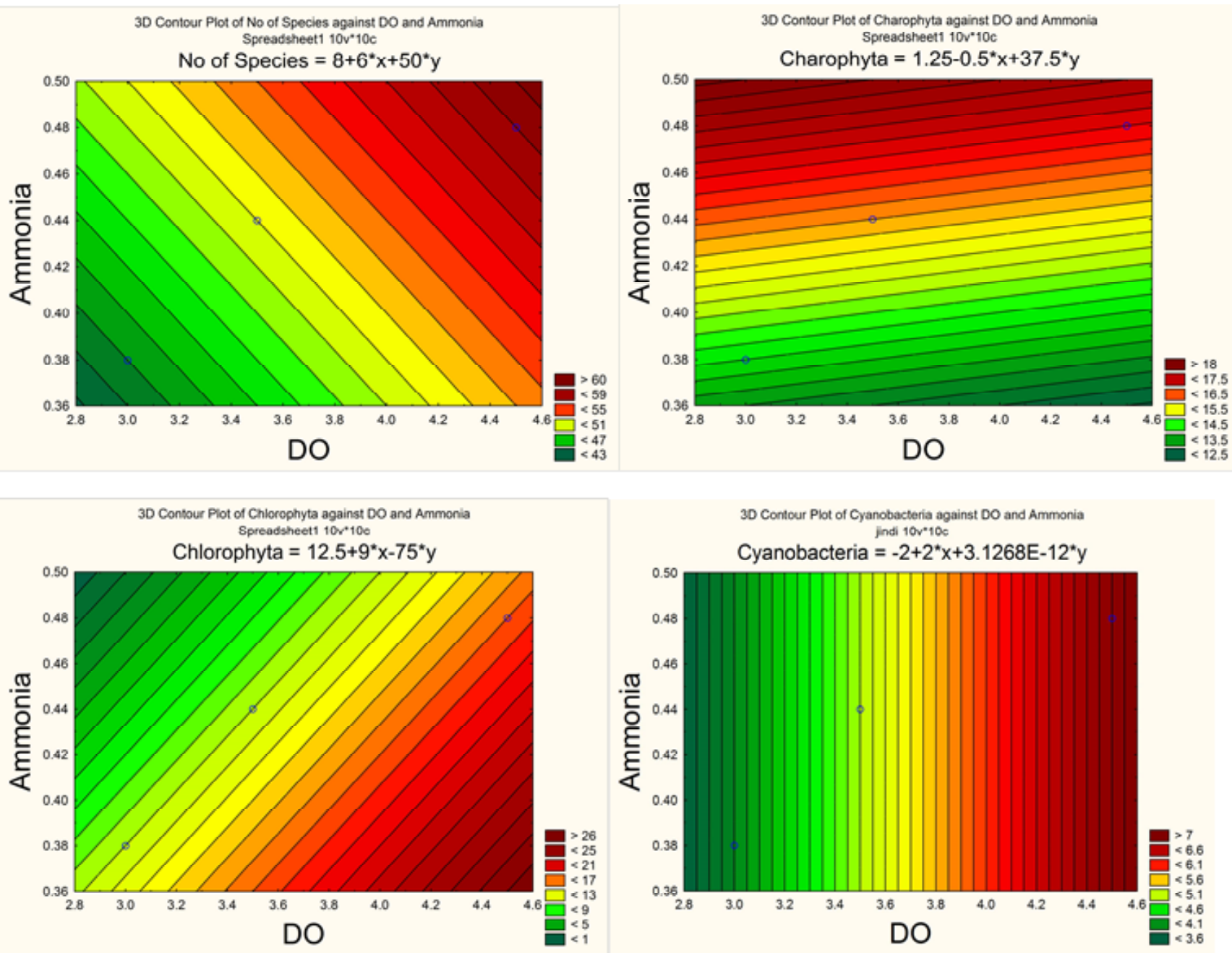

Fig. 5. 3D Contour plots of relationships between species richness against ammonia and oxygen concentrations in the Jindi River, March-May 2016

Рис. 5. 3D контурные плоты, отражающие взаимосвязь видового богатства и содержания аммиака и кислорода в р. Джинди, март-май 2016 г.

insignificantly with the decrease from the upper sites down the river. Ramakrishnan [20] reported that water temperature in this region increases from December $\left(23.1{ }^{\circ} \mathrm{C}\right)$ to July $\left(30.1{ }^{\circ} \mathrm{C}\right)$. FWPCA (Federal Water Pollution Control Administration) [21] stated that all the stations presented values ranging between $10{ }^{\circ} \mathrm{C}$ in February and $34{ }^{\circ} \mathrm{C}$ in June, meaning that our measurements with about $26{ }^{\circ} \mathrm{C}$ fall into the climatic range of the region. The other environmental variables also ranged insignificantly at the sites during the low water season. Water $\mathrm{pH}$ varied between 8.45 and 9.80, which shows the pollution impact at the sites during the low water spring season. It is confirmed by the study of Ramakrishnan [20] as a result of an increased concentration of bicarbonate alkalinity during AprilMay in this region.
Khan et al. [22] reported that water turbidity is caused by the presence of suspended particles of clay or silt and colloidal organic materials that can be seen at the upper sites of the investigated area. The ammonia concentration was maximal at the lower site of Charsadda. It can usually be related to organic matter and evidence its enriching of the river water from the upper sites to the lower ones. Gupta et al. [23] stated that the presence of ammonia in water is a significant indication of pollution due to untreated domestic, industrial sewage effluents.

Comparison of the current research results for this region to those received earlier shows similarity with the pollution dynamics situation in the Jindi River and the Kabul River $[8,9]$ as well as the lower reaches of the Swat River [7], where charophytes and green algae 
significantly prevail. In contrast to the mentioned rivers, water turbidity in the Jindi River decreased downstream. The water $\mathrm{pH}$ parameter was highest in the studied Kabul River basin to compare with the rivers Mardan [10, 12], Kabul [9], Shah Alam [11] and the lower part of the Swat River [7]. Species diversity in the algal communities of the Jindi River was similar to the one in the other regional rivers $[7-9,11,12]$, except for the upper part of the Swat River [6] and the Mardan River [10] where diatoms prevailed.

\section{CONCLUSION}

The first step of the studies on the algae diversity in the Jindi River during the low water season in MarchMay, 2016 included identification of species richness and revealing the major influential factors for its development. Altogether, 93 algal species from five taxonomic divisions were reported in 90 samples collected at three different sites. The Charophyta species significantly prevailed. Total species richness increased from the upper sites of Shabqadar and Tangi to the lower site of Charsadda. The algal community of NaviculaSpirogyra and Nitzschia-Spirogyra at the upper sites dramatically changed to Cladophora-UlothrixSpirogyra-Oscillatoria at the lower site of Charsadda. Simultaneously, the algal communities demonstrated high uniformity with the major role of diatoms, charophytes, and green algae at each site. It was found out that riverine algal community was enriched by cyanobacteria at the lower site of Charsadda with a decreasing role of diatom species. It can be caused by the influence of water pollution down the river.

Water parameters of temperature, turbidity, and TDS varied insignificantly during the spring season. At the same time, water $\mathrm{pH}$ was rather high (up to 9.8) increasing at the lower site of Charsadda, which can show the pollution impact. Nevertheless, the river water can be characterized as fresh, with minimal salinity and dissolved oxygen sufficient for the aquatic life survival. As a positive tendency we can mention the decrease of water turbidity and total suspended solids down the river, so water was more transparent at the Charsadda site, which helps the algal community in a selfpurification process. However, the ammonia content was maximal at this site, which indicates moderately polluted water.

Statistical methods reveal the fact that ammonia and oxygen were two major environmental factors that influenced algal diversity and significantly correlated with species richness. The CCA plot combined the environmental variables into three groups, which influenced algal diversity. The statistical analysis shows that total species richness was stimulated by ammonia and dissolved oxygen. Charophytes were more tolerant to ammonia than green algae. It is essential that cyanobacteria species increased in number with the oxygen increase down the river, which demonstrates high ability of the Jindy River ecosystem towards selfpurification with the help of algal communities.

\section{ACKNOWLEDGEMENTS}

The research was partly supported by the Israeli Ministry of Aliya and Integration.

\section{REFERENCES}

1. Salam A., Shah Z., Ullah K., Khan I., Khan F.A., Ahmad N., Khan K. Effect of $\mathrm{pH}$ and temperature on the efficiency of indigenous algae to remove contaminants from artificial wastewaters. Journal of Agriculture and Veterinary Science, 2014, no. 7 (3), pp. 62-72.

2. Batiuk R.A., Orth R.J., Moore K.A., Dennison W.C., Stevension J.C., Staver L.W., Carter V., Rybicki N.B., Hickman R.E., Kollar S., Bieber S., Heasly P. Chesapeake Bay submerged aquatic vegetation habitat requirements and restoration targets: a technical synthesis. Annapolis: U.S. Environmental Protection Agency Publ., 1992, $186 \mathrm{p}$.

3. Dokulil M.T. Algae as ecological bio-indicators. In: Trace metals and other contaminants and the environment. Vol. 6. Bioindicators \& biomonitors: principles, concepts and applications. B.A. Markert, A.M. Breure, H.G. Zechmeister. (Eds.). Ann Arbor: Elsevier, 2003, pp. 285-327.

4. Barinova S. Essential and practical bioindication methods and systems for the water quality assessment. International Journal of Environmental Sciences \& Natural Resources, 2017, no. 2 (3), pp. 1-11. doi: 10.19080/IJESNR.2017.02.555588.

5. Rovira L., Trobajo R., Ibanez C. Periphytic diatom community in a Mediterranean salt wedge estuary: the Erbo Estuary (NE Iberian Peninsula). Acta Botanica Croatica, 2009, no. 68 (2), pp. 285-300.

6. Barinova S., Ali N., Barkatullah, Sarim F.M. Ecological adaptation to altitude of algal communities in the Swat Valley (Hindu Cush Mountains, Pakistan). Expert Opinion on Environmental Biology, 2013, no. 2 (2), pp. 1-15. doi: 10.2478/s13545-014-0150-y.

7. Khuram I., Ahmad N., Jan S., Barinova S. Freshwater green algal biofouling of boats in the Kabul River, Pakistan. Oceanological and Hydrobiological Studies, 2014, no. 43 (4), pp. 329-336. doi: 10.2478/s13545-014$0150-\mathrm{y}$.

8. Barinova S., Khuram I., Asadullah, Ahmad N., Jan S., Shin D.H. How water quality in the Kabul River, 
Pakistan, can be determined with algal bio-indication. Advance Studies in Biology, 2016, no. 8 (4), pp. 151171.

9. Khuram I., Barinova S., Ahmad N., Ullah A., Siraj U.D., Jan S., Hamayun M. Ecological assessment of water quality in the Kabul River, Pakistan, using statistical methods. Oceanological and Hydrobiological Studies, 2017, no. 46 (2), pp. 140-153. doi: https://doi.org/ 10.1515/ohs-2017-0015.

10. Mursaleen, Shah S.Z., Ali L., Ahmad N., Kuram I., Barinova S.S. Algal communities of the Mardan River in ecological assessment of water quality in district Mardan, Pakistan. MOJ Ecology \& Environmental Sciences, 2018, no. 3 (2), pp. 82-92. doi: 10.15406/ mojes.2018.03.00071.

11. Khuram I., Muhammad Z., Ahmad N., Ullah R., Barinova $\mathrm{S}$. Green and Charophyte algae in bioindication of water quality of the Shah Alam River (District Peshawar, Pakistan). Transylvanian Review of Systematical and Ecological Research, "The Wetlands Diversity”, 2019, no. 21.1, pp. 1-16. doi: 10.2478/trser-2019-0001.

12. Mursaleen, Shah S.Z., Ali L., Ahmad N., Khuram I., Barinova S. Bioindication of water quality by algal communities in the Mardan River, Pakistan. International Journal of Biology and Chemistry, 2018, no. 11 (1), pp. 65-81.

13. Edler L., Elbrächter M. The Utermöhl method for quantitative phytoplankton analysis. In: Microscopic and molecular methods for quantitative phytoplankton analysis. Paris: UNESCO Publ., 2010, pp. 12-13.

14. Syed A.A. Atlas of Pakistan. Rawalpindi: Survey of Pakistan Publisher, 1990.

15. Land use atlas of Pakistan. Government of Pakistan. Ministry of Environment Publ., 2009, 77 p. Available at: https://wedocs.unep.org/bitstream/handle/20.500.11822/
9393/-Land_Use_Atlas_of_Pakistan-2009 Pakistan_Land $\bar{d}$ Use Ātlas_2009.pdf.pdf? (accessed 08.11.2018).

16. Standard methods for the examination of water and wastewater (19 ${ }^{\text {th }}$ edition). A.E. Greenberg, L.S. Clesceri, A.D. Eaton. (Eds.). Washington DC: APHA, AWWA, WPCF Publ., 1995, 1100 p.

17. Prescott G.W. Algae of the western Great Lakes area. Bloomfield Hills: Cranbrook Institute of Science Publ., 1951, $946 \mathrm{p}$.

18. Tiffany L.H., Britton M.E. The algae of Illinois. Chicago: Chicago University Press, 1952, 406 p.

19. Desikachary T.V. Cyanophyta. New Dehli: Indian Council of Agriculture Research Publ., 1959, 669 p.

20. Ramakrishnan N. Bio-monitoring approaches for water quality assessment in two water bodies at Tiruvannamalai, Tamil Nadu India. In: Proceedings of the Third International Conference on Environment and Health. (Chennai, India, 15-17 December, 2003). Chennai: University of Madras Publ., 2003, pp. 374-385.

21. Water quality criteria: report of the National Technical Advisory Committee to the Secretary of the interior U.S. coastal cities. New York: FWPCA (Federal Water Pollution Control Administration) Publ., 1968, pp. 32-34.

22. Khan N., Syed T.H., Abdus S., Nargis J., Kyong S.K. Physicochemical investigation of the drinking water sources from Mardan, Khyber Pakhtunkhwa, Pakistan. International Journal of Physical Sciences, 2013, no. 8 (33), pp. 1661-1671.

23. Gupta N., Nafees S.M., Jain M.K., Kalpana S. Physicochemical assessment of water quality of River Chambal in Kota City area of Rajasthan State (India). Rasayan Journal of Chemistry, 2011, no. 4 (2), pp. 686-692.

Поступила 31.10.2018

Принята к печати 09.12.2018 